\title{
A Study on the Factors Affecting the Accuracy of Surplus Forecast in Securities Analysis
}

\author{
Zhang Tianming \\ Department of Finance Management, Questrom school of business, Boston university, 02115, US
}

Keywords: Securities analyst; statistical model; earnings forecast; relative accuracy

\begin{abstract}
With the rapid development of China's economy, the securities industry in China develops rapidly. Before the investors invest in securities, people will be based on professional earnings forecast to select the specific investment to invest in the project, there are two main ways of the current earnings forecast, one is through the statistical model to predict, and one is the securities analyst for earnings forecast. In contrast to the two forecasting methods, we find that if the annual historical data is based, then the earnings forecast made by our securities analysts is smaller than the earnings forecast error obtained from the statistical model. If the quarterly historical data is based, securities analysts' earnings predictions are worse than earnings estimates by the statistical model. Based on this situation, we need to examine accuracy and its determinants of the analyst's earnings forecast relative to the statistical model of earnings forecast. Based on the explanation of the concept of the securities analyst and the hypothesis of the hypothesis, the author makes a model design based on the earnings forecast data of some listed companies in China in 2005, and finally obtains the relative accuracy and determinants of the analyst's earnings forecast relative to the statistical model.
\end{abstract}

\section{The Concepts and Development of Securities Analysts in China}

Securities analysts mainly work in the brokerage or fund, securities and other advisory bodies, they will collect moral data and information to analyze the stock market, and then publish earnings forecasts to investors and make recommendations for their investment. With the securities analyst's earnings forecast, investors not only can make more accurate securities investment, but also can make market information more symmetrical, and promote the rational allocation of resources in the market. In the study of the securities analysts to predict earnings, the most important thing is the accuracy of its research, only the accuracy of the higher forecast is effective. In the more mature foreign securities market, the earnings forecast made by the securities analyst using the professional knowledge and the real-time data is higher than the surplus forecast made by the statistical model. However, in our relatively immature securities market, the accuracy of the earnings forecast and the international general result are not the same due to the late start of the securities analyst industry and the lack of professional guidance. Therefore, we need to analyze the relative accuracy of China's securities analyst's earnings forecast based on time, which can help investors to make a choice between the analyst's forecast and the statistical model forecast, but also help to promote China's securities analysis industry to develop.

\section{The Hypothesis of Relative Accuracy of Earnings Prediction of Securities Analysts}

The securities earnings forecast mainly through three ways which are the securities analysts forecast, statistical model, and company management issued. However, in our country, the management of the company will not publish the information on the earnings forecast. In order to study the relative accuracy of China's securities analysis earnings forecast, we mainly take the securities analyst forecast and statistical model to do comparison. When using the statistical model for earnings forecasting, it is only necessary to bring the relevant data into the corresponding model to arrive at the conclusion. When the securities analyst carries out the earnings forecast, it needs to 
use various methods, knowledge, the process is relatively cumbersome, therefore, if the securities analyst making the earnings forecast is not an absolute advantage, there is no need for the existence.

\section{The accuracy of the earnings forecast made by the securities analyst is higher than the earnings forecast made by the statistical model.}

The securities analysts making the earnings forecast should be more advantages. First of all, the analyst's flexibility is relatively high, and he can arrange the most appropriate time series model. It is necessary to make certain adjustments in real terms. Second, he can collect and use the latest real-time data in the analysis process, which is what the statistical model cannot do; in addition, the securities analyst has a comprehensive, professional knowledge. The statistical model can only be fixed on the specific aspects of a fixed analysis, and securities analysts can be multi-faceted to consider the issue. In the reverse direction, securities analysts have the advantage of being predictable because they are biased, but they also deviate from the perceived uncertainty. For example, earnings analysts with knowledge reserves and experienced analysts are less likely than experienced. There is a lot of analysts who may be based on the cost of the business to determine the authenticity of the published data, so all of which may lead to the securities analyst earnings forecast accuracy to reduce.

\section{The specific circumstances of the listed company will have an impact on the relative accuracy of the earnings analyst's earnings forecast.}

We describe the factors that affect the relative accuracy of the earnings analyst's earnings forecast and the statistical model's earnings forecast from the three aspects of the listed company. First of all, compared to small companies, large companies because of high credibility, easy flow of stocks and other reasons will be more favored by investors, securities analysts are likely to meet the needs of investors, the focus will be on the big companies .The relative accuracy of earnings forecast for large companies is higher than the relative accuracy of earnings forecast for small companies. Secondly, the surplus forecast of statistical model is based on historical data to formula for the analysis of the operation, if a company's historical data fluctuations are relatively large, then the statistical model to predict the accuracy is relatively low. Finally, the length of time the company's listing will have an impact on the accuracy of the earnings forecast, the longer the company has its own relationship, it will not disclose internal information to the analyst, and the new listing of the company in order to go fast into the industry relations network, it will take the initiative to provide some internal information for securities analysis. For example, the more accurate the earnings are, the more accurate the forecast is, and the relative accuracy of the earnings forecasts made by the securities firm is relatively high.

\section{The times when the securities analyst issues the earnings forecast affect the accuracy.}

As we all know, the market is unpredictable, the more predictable of surplus data, the higher accuracy of the surplus forecast, statistical models for earnings forecasting takes some time, the various data generated during the forecast cannot be used, But the flexibility of the analyst's earnings forecast is relatively high, he can add the latest data at any time in the forecast, so the earnings forecast is relatively late, the securities analysts get more information, the accuracy is more better.

\section{Analysis of the design, process and results}

\section{A comparative test of the relative accuracy between the earnings forecast and the statistical model made by the securities analyst}

The relative accuracy of the analyst's earnings forecast (AA) is the difference between the absolute value of the forecast earnings per share forecast and the absolute value of the earnings 
analyst's earnings forecast. |EFEFA| is absolute value of the difference between the earnings per share (EFFA) and the actual earnings per share (AE). |EFETS| is the absolute value of the difference between the earnings per share forecast (EFTS) and the actual earnings per share (AE).If AA is greater than 0 , the relative accuracy of the earnings forecast of the securities analyst is higher than the earnings forecast based on the statistical model. If AA is less than 0 , the relative accuracy of the earnings forecast based on the statistical model is higher than the earnings forecast made by the securities analyst.

\section{Securities analyst forecast error and statistical model forecast error description statistics} table

\begin{tabular}{|l|l|l|l|l|l|l|l|l|}
\hline & $\mid$ EFEFA $\mid$ & $\mid$ EFETs $\mid$ & $\mid$ EFETS2 $\mid$ & $\mid$ EFETs $\mid$ & $\mid$ EFETS4 $\mid$ & $\mid$ EFETs5 $\mid$ & $\mid$ EFETS6 $\mid$ & $\mid$ EFETs7 $\mid$ \\
\hline Mean & 0.151 & 0.192 & 0.261 & 0.301 & 0.221 & 0.152 & 0.122 & 0.181 \\
\hline Median & 0.068 & 0.100 & 0.140 & 0.123 & 0.126 & 0.080 & 0.061 & 0.091 \\
\hline 25\% Score & 0.027 & 0.040 & 0.056 & 0.049 & 0.052 & 0.036 & 0.024 & 0.035 \\
\hline 75\% Score & 0.157 & 0.210 & 0.290 & 0.300 & 0.249 & 0.189 & 0.143 & 0.212 \\
\hline $\begin{array}{l}\text { Standard } \\
\text { deviation }\end{array}$ & 0.088 & 0.154 & 0.445 & 0.315 & 0.115 & 0.044 & 0.036 & 0.071 \\
\hline Observations & 2144 & 2144 & 2144 & 2069 & 1661 & 2040 & 2040 & 2014 \\
\hline
\end{tabular}

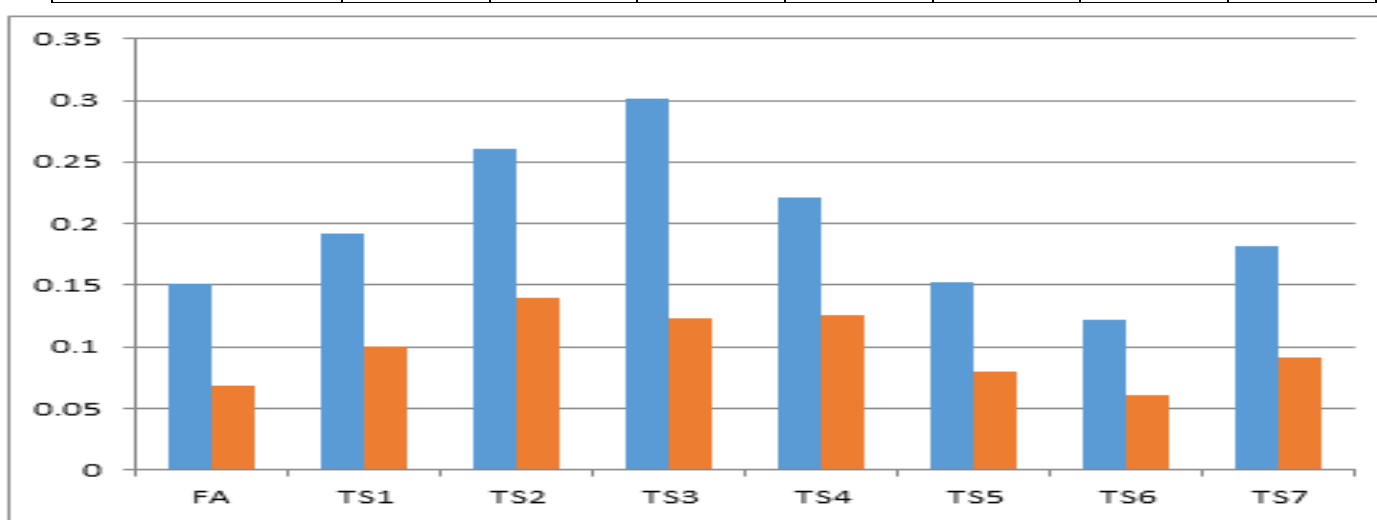

Comparison of Predictive Errors between Analysts and Statistical Models

The above tables and graphs use the data and comparison graphs to express the earnings analyst's earnings forecast and the relative accuracy of the earnings forecast based on the statistical model. The table clearly shows the results of EFEFA and EFETS1 to EFETS7, while the bar graphs show the results of the graph more vividly. From the table, it is easy to find that the mean and median of the earnings forecast error | EFEFA |, based on the annual historical data, are 0.151, 0.068. The most accurate set of mean and median were $0.192,0.100$.Obviously, the earnings forecast error on behalf of the securities analyst | EFEFA | is smaller than the prediction error (| EFETS1 $|\sim|$ EFETS4 |) on behalf of the statistical model. When the quarterly historical data is based on the earnings analyst's earnings forecast error | EFEFA | the mean and median are also 0.151 and 0.068. And the most accurate mean and median values obtained from the statistical model are 0.122 , 0.061. Therefore, in this case, the earnings forecast error on behalf of the securities analyst | EFEFA | than the statistical error of the statistical model (| EFETS1 $|\sim|$ EFETS4 $\mid$ ) to large. Based on the above two figures, we can conclude that the accuracy of the earnings forecast made by the securities analyst in the case of annual data is high, and the accuracy of the earnings forecast made by the securities analyst is low based on the quarterly data.

In summary, the earnings forecast made by the securities analyst has some advantages over the earnings forecast derived from the annual statistical model, but the earnings analysts' earnings estimates relative to the simple quarterly statistical model. There is no advantage in earnings forecast. This is the development of China's securities analysis industry to bring some inspiration, analysts need to improve their professional skills, be aware of the relevant experience abroad to learn. 


\section{A Study on the Influencing Factors of Earnings Accuracy of Securities Analyst}

In order to test the factors that affect the relative accuracy of the earnings analyst's earnings forecast, we construct the following model:

$$
\mathrm{AA}=\mathrm{b} 0+\mathrm{b} 1 \mathrm{VAR}+\mathrm{b} 2 \mathrm{SIZE}+\mathrm{b} 3 \mathrm{AGE}+\mathrm{b} 4 \mathrm{TIME}+\mathrm{b} 5 \mathrm{NANA}+\mathrm{b} 6 \text { IND }+\varepsilon
$$

VAR is the variance of historical earnings per share earnings of listed companies. VAR Y is the standard deviation of earnings per share, indicating the volatility of the surplus, which is used to compare with the annual model data. V AR Q is the variance of the four-quarter earnings per share, indicating the volatility of the quarterly surplus, used to compare with quarterly model data. SIZE refers to the size of the listed company; AGE refers to the company's time to market. TIME is the relative time that the securities analyst makes the earnings forecast. When we compare with the annual model data, we use the month of the forecast by the securities analyst to be recorded as TIME Y. When we compare with the quarterly model data, the date of the forecast is expressed as TIME $Q$ from the number of days between the dates the listed company issued the quarterly earnings information date. NANA is tracking the number of securities analysts with the same company.

\section{Regression variable description statistics table}

\begin{tabular}{|l|l|l|l|l|l|l|l|}
\hline & VAR_Y & VAR_Q & SIZE & TIME_Y & TIME_Q & NANA & AGE \\
\hline Mean & 0.126 & 0.048 & 12.708 & 8.512 & 44.193 & 4.734 & 7.095 \\
\hline Median & 0.087 & 0.034 & 12.572 & 9.000 & 43.000 & 5.000 & 7.000 \\
\hline Maximum & 7.828 & 0.888 & 18.111 & 12.000 & 128.00 & 13.000 & 16.000 \\
\hline Minimum & 0.001 & 0.001 & 8.326 & 1.000 & 1.000 & 1.000 & 1.000 \\
\hline $\begin{array}{l}\text { Standard } \\
\text { deviation }\end{array}$ & 0.212 & 0.058 & 1.213 & 2.715 & 27.528 & 2.277 & 3.612 \\
\hline
\end{tabular}

Based on the previous analysis, we analyzed the factors such as the size of listed companies, the volatility of earnings per share, the time of listing, and the number of securities analysts, forecasting time and other related factors. Finally, the conclusion is that the larger the company, the greater the volatility of the stock index, the later the listing, the higher the relative accuracy of the earnings forecast made by the securities analyst, the later the earnings analyst makes the forecast.

\section{Conclusion}

The securities industry is the product of China's economic development. Earnings forecast play an important role in promoting the development of securities industry. This paper makes a comparison between the two methods of earnings forecast in the securities industry by using the situation of modeling and analysis, and examines the statistical accuracy of the two kinds of forecasting methods in China's securities industry. Based on this, the paper analyzes the factors that affect the accuracy of earnings forecast of securities analysts. Finally, it is concluded that the earnings forecast made by the securities analyst has some advantages over the earnings forecast derived from the annual statistical model. Based on this result, China can explore the right path for the development of national securities analysts.

\section{References}

[1] Wu Donghui, XueZuyun 2005. An Empirical Analysis of Earnings Prediction of Financial Analysts in China's A-share Market. China Accounting and Finance Research

[2] Hu Yiming, Sun Congying. 2005. Foreign securities analyst earnings forecast empirical study. Securities market guidance 
[3] Xu Xiushi. 1993. Financial analyst earnings prediction superiority determinants of empirical research.

[4] Zhang Qiaoliang, Zhang Qing.Effects of securities company compliance culture on analyst 's earnings forecast accuracy [J]. 